\title{
ANALISIS KOMPARATIF TINGKAT KESEJAHTERAAN RUMAH TANGGA PETANI KARET DESA SUNGAI JALAU DENGAN DESA TERATAK KABUPATEN KAMPAR
}

\author{
Yusmini, Shorea Khaswarina, Evy Maharani \\ Jurusan Agribisnis Fakultas Pertanian UniversitasRiau \\ E-mail: miny_agb1@yahoo.co.id
}

\begin{abstract}
This study aims to analyze the rubber farm income and household welfare level comparison of farmers in Desa Sungai Jalau and Desa Teratak. The results showed net income and labor income off arm families during the one-year analysis of rubber, a rubber farmer Desa Sungai Jalau net income of Rp11,253,051.5/ha and labor income families Rp17,833,933.8/ha, while the net income per farmer Desa Teratak year amounted to USD11,316,228.1/ha and labor income families Rp18,352,591.7/ha, net income and income of farming families working rubber farmer Desa Teratak is greater than Desa Sungai Jalau respectively $0.56 \%$ and $2.91 \%$. The average of rubber farmers in Desa Sungai Jalau and Desa Teratak is welfare, based on the test there were significant differences in the level of well-being that significant in the community Desa Sungai Jalau with Desa Teratak.
\end{abstract}

Keyword: Structure, household income, rubber farmers

\begin{abstract}
Abstrak: Penelitian ini bertujuan untuk menganalisis pendapatan usaha tani karet dan perbandingan tingkat kesejahteraan rumah tangga petani di Desa Sungai Jalau dan Desa Teratak. Hasil penelitian menunjukan pendapatan bersih dan pendapatan kerja keluarga petani karet selama satu tahun analisis, pendapatan bersih petani karet Desa Sungai Jalau sebesar Rp11.253.051,5/ha dan pendapatan kerja keluarga sebesar Rp17.833.933,8/ha, sedangkan pendapatan bersih petani Desa Teratak pertahun sebesar Rp11.316.228,1/ha dan pendapatan kerja keluarga sebesar Rp 18.352.591,7/ha, pendapatan bersih dan pendapaan kerja keluarga per hektar usaha tani karet petani Desa Teratak lebih besar dari Desa Sungai Jalau masing-masing $0,56 \%$ dan 2,91\%. Rata-rata petani karet di Desa Sungai Jalau dan Desa Teratak sudah sejahtera, berdasarkan uji significant terdapat perbedaan tingkat kesejahteraan yang significant pada masyarakat Desa Sungai Jalau dengan Desa Teratak.
\end{abstract}

Kata kunci: Struktur, Pendapatan Rumah tangga, Petani Karet

\section{PENDAHULUAN}

Pengembangan perkebunan karet di Indonesia menjadi salah satu titik perhatian pemerintah Indonesia, karena memiliki kontribusi yang cukup signifikan terhadap perekonomian daerah maupun nasional, dalam hal penyediaan lapangan kerja dan sumber pendapatan utama masyarakat, penciptaan nilai tambah dan penyumbang devisa negara. Ada tiga bentuk pengelolaan perkebunan karet yang ada di Indonesia yaitu Perkebunan swadaya/ Perkebunan Rakyat (PR), Perkebunan Besar
Negara (PBN) dan Perkebunan Besar Swasta (PBS). Pada tahun 2011 produktivitas perkebunan karet rakyat atau pola swadaya sebesar $926 \mathrm{~kg} / \mathrm{ha} /$ tahun sedangkan produktivitas perkebunan besar 1.560 $\mathrm{kg} / \mathrm{ha} /$ tahun, angka ini menunjukan produktivitas perkebunan karet rakyat lebih rendah 40,64\% dari perkebunan besar (Direktorat Jenderal Perkebunan, 2012).

Perkebunan karet tersebar di berbagai provinsi di Indonesia salah satunya di Provinsi Riau, pemerintah daerah Riau mengembangkan perkebunan karet sebagai salah satu alternatif 
pembangunan ekonomi pedesaan. Salah satu wilayah penghasil karet di Provinsi Riau adalah kabupaten Kampar, berdasarkan wilayah potensi pengembangan komoditi karet, kabupaten Kampar memiliki wilayah pengembangan karet terluas kedua setelah Kabupaten Kuantan Singingi. Pada tahun 2010 luas kebun karet di kabupaten Kampar mencapai 101.174 hektar atau sebesar 20 persen, dengan produksi 67.624 ton atau 19 persen dari produksi total provinsi Riau (BadanPusatStatistik, 2011).

Perkebunan karet rakyat di Kabupaten Kampar sudah membudaya dalam kehidupan masyarakat sehari-hari, umumnya diusahakan oleh petani dalam skala kecil dengan sistem tradisional. Beberapa kecamatan merupakan sentra produksi karet di Kabupaten Kampar, diantaranya Kecamatan Kampar Utara dan Kecamatan Rumbio Jaya. Luas kebun karet di Kecamatan Kampar Utara tahun 2010 adalah $3.853 \mathrm{Ha}$ dengan Tanaman Belum menghasilkan (TBM) seluas 284 hektar, Tanaman Menghasilkan (TM) seluas 2.218 hektar dan Tanaman Tua Rusak seluas 1.350 hektar. Jumlah Produksi tahun 2010 adalah 2.502 ton/ tahun. Kecamatan Rumbio Jaya terdapat tanaman belum menghasilkan (TBM) seluas 2.677 hektar, tanaman menghasilkan (TM) seluas 1.189 hektar dan tanaman tua rusak seluas 210 hektar. Jumlah Produksi tahun 2010 adalah 1.125 ton/tahun (Dinas Perkebunan Kabupaten Kampar, 2011). Sebesar 35,1\% tanaman karet rakyat dikampar utara merupakan tanaman tua rusak dan sebesar 50\% tanaman menghasil berumur diatas 25 tahun, sedangkan tanaman karet mempunyai umur ekonomis 25 tahun. Kondisi secara relatif besarnya jumlah tanaman tua renta dan sekitar 50\% tanaman karet menghasilkan berumur diatas 25 tahun, juga terjadi di Kecamatan Rumbio, hal ini akan mengakibatkan rendahnya produktivitas dan pendapatan petani karet.

Desa Sungai Jalau adalah salah satu Desa yang ada di Kecamatan Kampar Utara dan Desa Teratak merupakan salah satu Desa di Kecamatan Rumbio Jaya, mayoritas pekerjaan utama penduduknya sebagai petani karet pola swadaya untuk memenuhi kebutuhan hidupnya sehari-hari, dalam memasarkan karet petani swadaya dilakukan melalui lembaga pemasaran yang ada di Desa dan luar Desa atau melalui tauke

Usaha perkebunan karet dijadikan sebagai penopang perekonomian masyarakat di Kabupaten Kampar, khususnya di Desa Sungai Jalau kecamatan kampar utara dan Desa Taratak Kecamatan Rumbio Jaya, dimana usaha perkebunan karet pola swadaya merupakan pekerjaan utama kepala keluarga. Pengelolaan usaha karet pola swadaya masyarakat dilakukan dengan pola tradisional ( tidak melakukan pemupukan berdasarkan tepat waktu, tepat jumlah dan tepat sasaran), banyaknya petani yang memiliki luas lahan yang relarif sempit karena lahan diperoleh dari warisan orang tua, relatif besarnya jumlah tanaman yang tua renta dan relatif banyaknya tanaman karet rakyat yang diusahakan sudah berumur lebih dari 25 tahun, produktivitas rendah dan harga cendrung turun dari tahun 2012 sampai 2014, apakah kondisi ini semua masih mampu memberikan pendapatan perkapita atau tingkat kesejahteraan yang layak bagi petani karet dalam memenuhi kebutuhan keluarganya.

Desa Sungai Jalau Kecamatan Kampar Utara dan Desa Taratak Kecamatan Rumbio Jaya Kabupaten Kampar, dua desa yang memiliki tauke yang berbeda dalam pemasaran produksinya. Pada Desa Sei Jalau semua taukenya berasal dari dalam desa atau tidak bolehnya tauke luar desa masuk sebagai tauke, tapi pada Desa Taratak bolehnya tauke luar Desa masuk atau membeli karet petani Desa Taratak, sedangkan harga tauke luar lebih tinggi dari tauke dalam. Perbedaan pemasaran/ tauke antara kedua Desa menyebabkan perbedaan harga jual karet, tauke menjadi pembuat harga sehingga harga jual menjadi bersaing,apakah perbedaan harga jual karet memberikan pengaruh terhadap pendapatan petani karet atau, apakah perbedaan harga betul-betul menyebabkan berbedanya pendapatan petani karet dan selanjutnya apakah perbedaan pendapatan uusahatani karet dapat membedakan tingkat kesejahteraan petani karet Desa Sungai Jalau dengan petani karet Desa Teratak.

Penelitianini bertujuanuntuk menganalisispendapatan usahatani karet dan menganalisis perbandingan tingkat kesejahteraan antara petanikaret di Desa Sungai Jalau 
Kecamatan Kampar Utara dan Desa Teratak Kecamatan Rumbio Jaya Kabupaten Kampar.

\section{METODE PENELITIAN}

Penelitian ini dilaksanakan di Kabupaten Kampar dengan pertimbangan bahwa, Kabupaten Kampar sebagai salah satu sentra produksi karet di Provinsi Riau, yang sebagian penduduknyabermata pencaharian sebagai petani karet. Kecamatan Kampar Utara dan Kecamatan Rumbio Jaya merupakan kecamatan penghasil karet di Kabupaten Kampar, Desa yang dipilih di Kecamatan Kampar Utara adalah Desa Sungai Jalau sedangkan di Kecamatan Rumbio Jaya adalah Desa Teratak. Pertimbangan dari pemilihan lokasi ini, masyarakat di dua desa ini mayoritas mengusahakan usahatani karet, tapi dalam pola pemasarannya terdapat perbedaan, di Desa Sungai Jalau tidak terdapatnya tauke dari luar desa, sedangkan di Desa Taratak terdapat tauke dari luar desa yang membeli karet petani.

Metode penelitian menggunakan metode survei, dengan mengadakan pengamatan langsung dilapangan dengan mewawancarai responden. Sebelum pengambilan sampel dilakukan, dengan terlebih dahulu didapatkan informasi dari kepala desa dan tokoh masyarakat tentang jumlah tauke di lokasi penelitian. Dari 6 jumlah tauke yang ada di Desa Sungai Jalau dan 8 tauke di Desa Teratak, diambil 50\% nya sebagai informan. Petani sampel diambil dari populasi petani yang menjual produksikaret ke touke yang terpilih sebagai informan. Pengambilan sampel dilakukan menggunakan metode purposive sampling, dengan kriteria luas lahan 1-2 hektar dan mengusahakan sendiri lahan karet (tidak dibagi hasilkan). Dari populasi petani karetnya yang menjual ke tauke (informan) di Desa Sungai Jalau dan Desa Teratak, diambil sampel masing-masing sebanyak 24 petani.

Analisis pendapatan usahatani karet seharusnya menggunakan analisa evaluasi proyek atau analisa pendapatan jangka panjang, yaitu menganalisa pendapatan selama usahatani tersebut dijalankan, karena tanaman karet merupakan tanaman yang memiliki umur panjang. Tujuan pada penelitian ini, selain menganalisis tingkat pendapatan usahatani karet juga menganalisis perbandingan tingkat kesejahteraan rumah tangga periode analisis satu tahun, karena itu pendapatan usahatani karet hanya dihitung selama periode analisis satu tahun., sehingga untuk mendapatkan berapa sebenarnya pendapatan usahatani karet pada satu tahun analisis, dilakukan asumsi terhadap biaya pembukaan lahan, sertifikasi lahan, biaya bibit dan biaya-biaya lain yang digunakan dari awal pembukaan lahan sampai masa sesaat sebelum produksi(TBM), dimana biaya investasi/TBM diasumsikan ditanggung sama besar sepanjang tahun produksi atau selama tanaman menghasilkan. Untuk mengetahui pendapatan usahatani petani karet, dilakukan dua analisis yaitu pendapatan perhektar dan pendapatan perluas garapan, karena penelitian ini juga menghitung pendapatan rumah tangga untuk menganalisis tingkat kesejahteraan, sehingga perlu dihtung penerimaan riil rumah tangga berdasarkan luas lahan yang dimiliki. Digunakan

Formulasi yang digunakan untuk menghiting pendapatan usahatani karet sebagai berikut (Soekartawi, 2002) :

$$
\begin{aligned}
& \prod=\mathrm{TR}-\mathrm{TC} \\
& \prod=\mathrm{Y} \cdot \mathrm{Py}-(\mathrm{TVC}-\mathrm{TFC}) \\
& \prod=\mathrm{Y} \cdot \mathrm{Py}-\left(\mathrm{X}_{1} \cdot \mathrm{Px}_{1}+\mathrm{X}_{2} \cdot \mathrm{Px}_{2}+\ldots+\mathrm{Xn} \cdot \mathrm{Pxn}+\mathrm{D}\right)
\end{aligned}
$$

\section{Dimana:}

$\Pi \quad$ : Pendapatan bersih (Rp)

TR : Pendapatan kotor (Rp)

TC : Biaya Produksi (Rp)

TVC : Total BiayaVariabel (Rp)

TFC : TotalBiayaTetap danTotal biaya TBM (Rp)

Y : JumlahProduksi $(\mathrm{kg})$

Py : HargaProduksi (Rp)

Xi..Xn : JumlahFaktorproduksi:benih, pupuk, tenagakerja, peralatan, dll

Pxi..Pxn: HargaFaktorProduksi (Rp)

\section{Tingkat Kesejahteraan Petani Karet}

Tingkat kesejahteraan rumah tangga pada penelitian ini, diukur dari pendapatan perkapita, sedangkan pendapatan perkapita didapat dari total pendapatan rumah tangga yang dibagi dengan seluruh anggota rumah tangga pada periode analisis satu tahun. Pendapatan rumah tangga petani karet adalah pendapatan dari seluruh anggota rumah tangga dari berbagai kegiatan produktif (pertanian dan non 
pertanian). Mengukur tingkat kesejahteraan rumah tangga petani karet pada penelitian ini ,diperoleh dengan membandingkan pendapatan perkapita petani karet dengan garis kemiskinan Provinsi Riau. Berbagai indikator yang bisa digunakansebagai ukuran tingkat kesejahteraan, dimana pada penelitian ini menggunakan indikator garis kemiskinan Provinsi Riau. Gariskemiskinandapat digunakan sebagai salah satu indikator kesejahteraan, karenagaris kemiskinan tersebut ditetapkan dengan menggunakan variabel-variabel kesejahteraan. Garis kemiskinan Provinsi Riau sebesar Rp 4.201.548/Kapita/Tahun, artinya masyarakat yang memiliki pendapatan perkapita pertahun sama dan besar dari garis kemiskinan sudah dikatakan sejahtera dan dibawah garis kemiskinan dikatakan tidah sejahtera( BPS, 2013)

Untuk melihat perbedaan tingkat kesejahteraan petani di Desa Sungai Jalaudan di Desa Teratak digunakan uji $t$ dengan membandingkan nilai t-hitung dengan t-tabel, dengan menggunakan rumus berikut : Dajan (1986)

$$
t=\frac{\overline{X 2}-\overline{X 1}}{\mathrm{sd} / \sqrt{\mathrm{n}}}
$$

Dimana:

$$
\begin{aligned}
\overline{X 1}= & \text { Rata-Rata pendapatan perkapita/ tahun } \\
& \text { petani di Desa Sungai Jalau } \\
\overline{X 2}= & \text { Rata-Rata pendapatan perkapita/ tahun } \\
& \text { petani di DesaTeratak } \\
\mathrm{Sd} & =\text { Standar Deviasi } \\
\square & =\text { Jumlah sampel }
\end{aligned}
$$

Ho diterima apabila $\mathrm{t}$ hitung $\leq \mathrm{t}$ tabel, $\mathrm{db}=\mathrm{n}-1$ dengan $\alpha=0,05$

Ho ditolak apabila $\mathrm{t}$ hitung $>\mathrm{t}$ tabel, $\mathrm{db}=\mathrm{n}-1$ dengan $\alpha=0,05$

\section{HASIL DAN PEMBAHASAN}

\section{Pendapatan Usahatani Karet per Tahun}

Biaya investasi/TBM usahatani karet mulai dari pembukaan lahan, penanaman, pemeliharaan dan pemupukan sampai umur lima tahun, pada Desa Sungai Jalau sebesar Rp 100.685.000/ha dan Desa Teratak sebesar Rp 120.817.250/ha. Investasi Desa Teratak lebih besar dari Desa Sungai Jalau sekitar 20\%, karena biaya penanaman dan perawatan, khususnya untuk jumlah pemakaian pupuk di Desa Teratak lebih besar dari Desa Sungai Jalau.

Luas lahan garapan petani Desa Sungai Jalau rata-rata 1,36 ha dan dan Desa Teratak 1,21ha, karena dalam penelitian ini selain menganalisis pendapatan petani karet dalam satuan hektar juga menganalisis pendapatan usahatani karet pada luas rataan lahan petani, maka nilai investasi diatas dikonversikan sesuai dengan luas garapan.Menurut Hernanto (1994), luas lahan garapan 0,5-2 ha termasuk pada luas lahan sedang, petani di lokasi penelitian memiliki luas lahan berkisar 1-2 ha, sehingga luas lahan petani karet termasuk luas lahan garapan sedang, tapi dari sisi luas lahan ratarata, petani Desa Sungai Jalau memiliki luas lahan rata-rata lebih luas dari petani Desa Terataksebesar 0,15 ha.

Harga karet yang ditawarkan tauke ke petani tergantung dari harga pabrik dan kualitas karet petani, walaupun petani mencoba melakukan negosiasi dengan tauke, tapi tetap saja tauke yang memutuskan pada harga berapa tauke akan membeli karet petani, artinya petani kurang memiliki posisi tawar menawar. Ratarata harga karet ditingkat petani Desa Sungai Jalau bulan November 2012 - Oktober tahun 2013 adalah Rp.8.558. Pada Desa Teratak harga tauke luar Desa lebih tinggi, namun perbedaan tersebut tidaklah terlalu signifikan, dimana harga rata-rata ditingkat petani November 2012 - Oktober tahun 2013 adalah Rp.8.593. Terdapat perbedaan harga rata-rata petani karet antara Desa Teratak dan Desa Sungai Jalau, dimana harga pada petani Desa Teratak lebih tinggi Rp.35/kg atau $0,4 \%$ dari patani Desa Sungai Jalau.

Harga karet di Desa Sungai Jalau dan Desa Teratak termasuk rendah dibandingkan harga yang berlaku di tingkat Kabupaten Kampar, dimana rata-rata harga ditingkat Kabupaten Kampar saat penelitian adalah Rp.9.150. Berbedaya harga rata-rata di Desa Sungai Jalau dan Desa Taratakdengan rata-rata harga di tingkat Kabupaten Kampar, karena kualitas karet di Desa Sungai Jalau dan Desa Teratak kurang bagus, hal ini disebabkan kurangnya kesadaran petani dalam meningkatkan kualitas karetnya,dimana adanya petani yang menambahkan kayu pada karetnya.

Pendapatan rata-rata petani karet Desa Sungai Jalau dan Desa Teratak selama satu 
tahun periode analisis, selain ditentukan oleh harga dan biaya total juga sangat ditentukan oleh produksi karet musim kemarau dan musim hujan. Pada Desa Sungai Jalau produksi pada musim kemarau sebesar $2550 \mathrm{~kg} / \mathrm{luas}$ garapan $(1875 \mathrm{~kg} / \mathrm{ha})$, dan rata-rata produksi pada musim hujan sebesar $1007 \mathrm{~kg} /$ luas garapan $(740,44 \mathrm{~kg} / \mathrm{ha})$, dimana produksi musim kemarau 2,53 kali (253\%) lebih besar dari musim hujan. Petani di Desa Teratak produksi karet rata-rata pada musim kemarau 2564 $\mathrm{kg} / \mathrm{luas}$ garapan $(2119 \mathrm{~kg} / \mathrm{ha})$ dan pada musim hujan $773 \mathrm{~kg} / \mathrm{luas}$ garapan $(638,84 \mathrm{~kg} / \mathrm{ha})$, dimana produksi rata-rata pada musim kemarau sekitar 3,32 kali (332\%) lebih besar dari musim hujan

Rendahnya produksi pada musim hujan dibanding musim kemarau, yang menyebabkan rendahnya pendapatan petani karet pada musim hujan dibandingkan dengan musim kemarau. Pada musim hujan petani tidak dapat menyadap karetnya setiap hari, rata-rata hanya 2-3 hari dalam seminggu, sedangkan pada musim kemarau petani bisa menyadapan 5-6 hari. Rendahnya produksi musim hujan yang menyebabkan rendahnya pendapatan pada musim hujan, sehingga petani harus meminjam uang kepada tauke, karena pendapatannya tidak mencukupi kebutuhan rumah tangganya. Petani tidak hanya meminjam uang untuk kebutuhan rumah tangga, tetapi juga untuk biaya sekolah anak. Uang yang dipinjamkan tauke ke petani tanpa bunga atau hal lain yang akan memberatkan petani, petani hanya punya keterikatan yaitu harus menjual produksi karetnya kepada tauke, dan harga karet yang diberlakukan sama kepada seluruh petani,baik yang meminjam uang maupun yang tidak. Pembayaran uang pinjaman tersebut dapat dilakukan dengan menyicil ketika menjual karet kepada tauke, dimana waktu/lamanya menyicil tidak ditetapkan dan petani dapat menyicil sesuai dengan kesanggupannya.

Rata-rata pendapatan bersih petani dari usahatani karet selama satu tahun analisis, merupakan penjumlahan dari pendapatan bersih musim kemarau dan musim hujan. Pendapatan yang diperoleh rumah tangga petani karet dalam mengusahakan usahatani karet dinamankan pendapatan keja keluarga, yang diperoleh dari pendapatan bersih usahatani karet ditambah dengan biaya tenaga kerja dalam keluarga (TKDK) dalam pengelolaan usahatani karet, karena TKDK dihitung sebagai biaya usahatani, tetapi merupakan pendapatan keluarga.

Pada Tabel 1 dapat dilihat pendapatan bersih dan pendapatan kerja keluarga petani karet selama satu tahun analisis per luas garapan. Pendapatan bersih usahatani karet per tahun Desa Sungai Jalau sebesar Rp. 15.304.150/Luas garapan (Rp 11.253.051,5/ha) dan pendapatan kerja keluarga sebesar Rp. 24.254.150/ luas garapan, (Rp 17.833.933,8/ha) sedangkan pendapatan bersih petani Desa Taratak per tahun sebesar Rp. 13.692.636/Luas garapan ( $\mathrm{Rp} \mathrm{11.316.228,1/ha)} \mathrm{dan} \mathrm{pendapatan}$ kerja keluarga sebesar Rp.22.206.636/ luas garapan ( $R p$ 18.352.591,7/ha). Pendapatan bersih per hektar petani Desa Teratak lebih besar $0,56 \%$ dari petani Sungai Jalau dan pendapatan kerja keluarga perhektar petani Desa Teratak lebih besar 2,91\% dari Desa Sungai Jalau. Kondisi tersebut disebabkan sedikit lebih tingginya harga jual karet ratarata petani Desa Taratak dari Petani Desa Sungai Jalau dan Petani Desa Teratak hampir semua pekerjaan dilakukan tenaga kerja dalam keluarga,sehingga biaya TKDK pada usahatani karet menjadi tambahan pendapatan kerja keliarga petani Desa Taratak.

Luas lahan rata-rata petani Desa Sungai Jalau lebih besar $12,40 \%$ dari Desa Teratak, sehingga pendapatan bersih perluas garapan yang diterima petani karet Desa Sungai Jalau juga lebih besar dari Desa Teratak sekitar 12\% ,sedangkan pendapatan kerja keluarga perluas garapan petani Desa Sungai Jalau hanya 9,22\% lebih besar dari Desa Teratak, karena patani Desa Taratak menerima pendapatan dari biaya TKDK lebih besar dari petani Desa Sungai Jalau.

Pendapatan petani karet di Desa Teratak, jika diasumsikan hanya berasal pendapatan usahatani karet saja, agar terpenuhi kebutuhan rumah tangga petani karet (petani berada pada kondisi sejahtera), maka dibutuhkan lahan lebih luas 1,38 Ha/KKatau sekurang-kurangnya sama 1,38 Ha/KK, karena masyarakat Provinsi Riau pada tahun 2013, yang memperoleh pendapatan perkapita pertahun lebih besar atau sekurangkurangnya 
Yusmini, Shorea K., Evy M. : Analisis komparatif tingkat kesejahteraan rumah tangga ...

Tabel 1. Analisis Usahatani Karet per Luas Garapan di Desa Sungai Jalau dan Desa Teratak per Tahun

\begin{tabular}{|c|c|c|c|c|c|c|c|c|}
\hline \multirow[b]{2}{*}{$\begin{array}{l}\mathrm{N} \\
\mathrm{o}\end{array}$} & \multirow[b]{2}{*}{ Keterangan } & \multicolumn{3}{|c|}{$\begin{array}{c}\text { Desa } \\
\text { Sungai Jalau } \\
\end{array}$} & & \multicolumn{3}{|c|}{$\begin{array}{c}\text { Desa } \\
\text { Teratak }\end{array}$} \\
\hline & & $\begin{array}{c}\text { Jumlah } \\
\text { Rata-Rata } \\
\quad(\mathrm{kg}, \\
\text { liter,HKP }\end{array}$ & $\begin{array}{l}\text { Harga } \\
\text { Rata- } \\
\text { Rata } \\
(\mathrm{Rp})\end{array}$ & $\begin{array}{c}\text { Total } \\
\text { Rata-rata } \\
(\mathrm{Rp})\end{array}$ & & $\begin{array}{c}\text { Jumlah } \\
\text { Rata- } \\
\text { Rata } \\
\text { (kg, } \\
\text { liter,HK } \\
\text { P }\end{array}$ & $\begin{array}{l}\text { Harga } \\
\text { Rata- } \\
\text { Rata } \\
\text { (Rp) }\end{array}$ & $\begin{array}{c}\text { Total } \\
\text { Rata-rata } \\
(\mathrm{Rp})\end{array}$ \\
\hline \multirow[t]{2}{*}{ A. } & $\begin{array}{l}\text { Biaya } \\
\text { Produksi }\end{array}$ & & & 15.136 .656 & $\begin{array}{l}\text { Total Biaya } \\
\text { Produksi }\end{array}$ & & & 14.973 .612 \\
\hline & $\begin{array}{l}\text { Biaya Tidak } \\
\text { Tetap }\end{array}$ & & & 369.112 & Biaya Tidak Tetap & & & 461.300 \\
\hline 1 & Pupuk & & & & Pupuk & & & \\
\hline a. & Urea & $30,36 \mathrm{~kg}$ & 4.575 & 138.879 & Urea & $50 \mathrm{~kg}$ & 5.000 & 250.000 \\
\hline b. & TSP & $5,36 \mathrm{~kg}$ & 5.400 & 28.944 & NPK & $2 \mathrm{~kg}$ & 7.000 & 14.000 \\
\hline c. & Dolomit & $39,29 \mathrm{~kg}$ & 500 & 19.645 & $\mathrm{KCl}$ & $13 \mathrm{~kg}$ & 4.850 & 63.050 \\
\hline \multirow[t]{2}{*}{ d. } & POSKA & $1,96 \mathrm{~kg}$ & 4.000 & 7.840 & Dolomit & $25 \mathrm{~kg}$ & 600 & 15.000 \\
\hline & Jumlah & & & 195.308 & Jumlah & & & 342.050 \\
\hline 2 & Herbisida & & & & Herbisida & & & 507.415 \\
\hline a. & Roundup & 0,07 liter & 70.000 & 4.900 & Round Up & 0,9 liter & 68.75 & 61.875 \\
\hline b. & Herbatok & 0,36 liter & 50.000 & 18.000 & Gramaxone & 0,9 liter & 63.75 & 57.375 \\
\hline \multirow[t]{2}{*}{ c. } & Gramoxon & 3,21 liter & 45.375 & 145.654 & Jumlah & & & 119.250 \\
\hline & Jumlah & & & 168.554 & & & & \\
\hline \multirow[t]{2}{*}{3} & TKLK & & & 5.250 & TKLK & & & - \\
\hline & Biaya Tetap & & & 14.767 .544 & Biaya Tetap & & & 14.512 .312 \\
\hline 1. & $\begin{array}{l}\text { Biaya } \\
\text { Penyusutan }\end{array}$ & & & 164.800 & Penyusutan Alat & & & 158.812 \\
\hline 2. & Biaya TKDK & & & 8.950 .000 & Biaya TKDK & & & 8.514 .000 \\
\hline 3. & $\begin{array}{l}\text { Biaya } \\
\text { Investasi th } 0- \\
5\end{array}$ & & & 5.652 .744 & $\begin{array}{l}\text { Biaya Investasi th } \\
0-5\end{array}$ & & & 5.839 .500 \\
\hline B. & $\begin{array}{l}\text { Penerimaan } \\
\text { dan } \\
\text { Pendapatan }\end{array}$ & & & & $\begin{array}{l}\text { Penerimaan dan } \\
\text { Pendapatan }\end{array}$ & & & \\
\hline 1. & $\begin{array}{l}\text { Penerimaan/ta } \\
\text { hun }\end{array}$ & $3.557 \mathrm{~kg}$ & 8.558 & 30.440 .806 & Penerimaan/tahun & $3.336 \mathrm{~kg}$ & 8.593 & 28.666 .248 \\
\hline 2 & $\begin{array}{l}\text { Penerimaan/b } \\
\text { ulan }\end{array}$ & & & 2.536 .734 & Penerimaan/bulan & & & 2.388 .854 \\
\hline 3 & $\begin{array}{l}\text { Pendapatan } \\
\text { bersih/tahun }\end{array}$ & & & 15.304 .150 & $\begin{array}{l}\text { Pendapatan } \\
\text { bersih/tahun }\end{array}$ & & & 13.692 .636 \\
\hline 4 & $\begin{array}{l}\text { Pendapatan } \\
\text { bersih/bulan }\end{array}$ & & & 1.275 .346 & $\begin{array}{l}\text { Pendapatan } \\
\text { Bersih/bulan }\end{array}$ & & & 1.141 .053 \\
\hline 5. & $\begin{array}{l}\text { Pendapatan } \\
\text { Kerja } \\
\text { Keluarga/ } \\
\text { tahun }\end{array}$ & & & 24.254 .150 & $\begin{array}{l}\text { Pendapatan Kerja } \\
\text { Keluarga/ } \\
\text { tahun } \\
\text { Pendapatan Kerja }\end{array}$ & & & 22.206 .636 \\
\hline 6. & $\begin{array}{l}\text { Pendapatan } \\
\text { Kerja } \\
\text { Keluarga/ } \\
\text { Bulan }\end{array}$ & & & 2.021 .179 & $\begin{array}{l}\text { Keluarga/ } \\
\text { Bulan }\end{array}$ & & & 1.850 .553 \\
\hline
\end{tabular}

Sumber: Data Primer Olahan, 2013 
Yusmini, Shorea K., Evy M. : Analisis komparatif tingkat kesejahteraan rumah tangga ...

Tabel 2. Total Rata-rata Pendapatan Rumah Tangga Petani Karet di Desa Sungai Jalau dan Desa Teratak per Tahun

\begin{tabular}{|c|c|c|c|c|c|}
\hline \multirow[b]{2}{*}{ No } & \multirow[b]{2}{*}{ Sumber Pendapatan } & \multicolumn{2}{|c|}{$\begin{array}{c}\text { Desa } \\
\text { Desa Sungai Jalau }\end{array}$} & \multicolumn{2}{|c|}{$\begin{array}{c}\text { Desa } \\
\text { Desa Taratak }\end{array}$} \\
\hline & & $\begin{array}{c}\text { Total } \\
\text { Pendapatan } \\
\text { (Rp/Tahun) }\end{array}$ & Persentase $(\%)$ & $\begin{array}{l}\text { Total Pendapatan } \\
\text { (Rp/Tahun) }\end{array}$ & $\begin{array}{l}\text { Persentase } \\
\quad(\%)\end{array}$ \\
\hline \multirow[t]{6}{*}{1} & Pendapatan Pertanian & & & & \\
\hline & Karet & 24.254 .150 & 63,21 & 22.206 .636 & 57,81 \\
\hline & Padi & 2.709 .216 & 6,80 & 734.160 & 1,91 \\
\hline & Sawit & 653.988 & 1,64 & 8.838 .792 & 23,04 \\
\hline & Nelayan & 862.284 & 2,16 & 766.992 & 2,00 \\
\hline & Sub Total & 29.402 .172 & 73,82 & 32.514 .948 & 84,76 \\
\hline \multirow[t]{12}{*}{2} & Pendapatan Nopertanian & & & & \\
\hline & PNS/Guru/Honorer & 4.806 .240 & 12,07 & - & - \\
\hline & Karyawan & 428.568 & 1,08 & - & - \\
\hline & Pedagang & 4.774 .788 & 11,99 & - & - \\
\hline & Perangkat Desa & 399.996 & 1,00 & - & - \\
\hline & Jasa bengkel & 19.284 & 0,05 & 748.248 & 1,95 \\
\hline & Pedagang Sembako & - & - & 1.140 .300 & 2,97 \\
\hline & Pedagang Besi & - & - & 2.655 .636 & 6,92 \\
\hline & Jasa Pangkas Rambut & - & - & 717.636 & 1,87 \\
\hline & Buruh Bangunan & - & - & 582.504 & 1,52 \\
\hline & Sub total & 10.428 .876 & & 5.844 .312 & \\
\hline & Total Rata-Rata & 39.831 .048 & & 38.359 .260 & \\
\hline
\end{tabular}

sama dengan $\mathrm{Rp}$ 4.201.548 dikatakan sudah sejahtera. Petani karet Desa Teratak dengan luas garapan 1,21 memperoleh pendapatan kerja keluarga dari usahatani karet sebesar Rp 22.175.004/tahun, dengan jumlah anggota keluarga rata-rata 6 orang, sehingga baru memperoleh pendapatan perkapita $\mathrm{Rp}$ 3.695.832. Agar meningkatnya pendapatan perkapita petani karet Desa Teratak lebih besa atau sama dengan Rp 4.201.548, perlu dilakukan penambahan luas lahan petani karet, sehingga petani memiliki lahan lebih besar atau sekurang-kurangnya sama dengan 1,38 $\mathrm{Ha} / \mathrm{KK}$ atau dibulatkan 1,5 Ha/KK. Pada Desa Sungai Jalau jika diasumsikan pendapatan rumah tangga juga hanya berasal dari pendapatan usahatani karet, agar terpenuhi kebutuhan rumah tangga petani karet, maka dibutuhkan luas lahan sekurang-kurangnya seluas 1,14 $\mathrm{Ha} / \mathrm{KK}$, karena masyarakat Provinsi Riau dikatakan sejahtera jika memiliki pendapatan perkapita minimal $\mathrm{Rp}$ 4.201.548/tahun, ratarata-rata anggota keluarga petani Desa Sungai Jalau 5 orang, sehingga perlu memperoleh pendapatan rumah tangga sebesar Rp
21.007.740/KK/tahun. Pendapatan usahatani karet ditambah dengan biaya TKDK yang diterima keluarga(pendapatan kerja keluarga) petani Desa Sungai Jalau saat penelitian sebesar Rp 18.512.265,2/Ha/tahun, sehingga untuk mendatangkan pendapatan sebesar Rp 21.007.740/KK/Tahun bisa diperoleh dari luas lahan minimal $1.14 \mathrm{Ha} / \mathrm{KK}$.

Luas lahan rata-rata petani karet Desa Sungai Jalau saat penelitian seluas 1,36 Ha/KK, dengan tingkat pendapatan perkapita pertahun dari usahatani karet sebesar Rp 5.035.336, sehingga berdasarkan harga karet dan tingkat kesejahteraan Provinsi Riau tahun 2013, petani Desa Sungai Jalau sudah memiliki luas lahan rata-rata yang dapat mendatangkan pendapatan perkapita pada kondisi sejahtera, artinya jika pendapatan rumah tangga hanya berasal dari usahatani karet saja,pada luas lahan garapan rata-rata petani Desa Sungai Jalau 1,36 $\mathrm{Ha}$ sudah dapat memenuhi kebutuhan petani. 


\section{Pendapatan per Kapita Rumah Tangga Petani Karet Tahun 2013}

Sumber pendapatan rumah tangga petani karet di Desa Sungai Jalau dan Desa Teratak, berasal dari jenis pekerjaan atau usaha dibidang pertanian dan nonpertanian. Tabel 2 menunjukkan bahwa pendapatan rumah tangga petani karet di Desa Sungai Jalau dan Desa Teratak, didominasi oleh usahatani karet yaitu masing-masing sebesar $63,21 \%$ dan $57,81 \%$, hal tersebut dikarenakan usahatani karet merupakan pekerjaan utama petani sampel . Semua jenis kegiatan produktif yang dilakukan rumah tangga petani karet Desa Sungai Jalau dan Desa Teratak masing-masing menghasilkan total rata-rata pendapatan rumah tangga $\mathrm{Rp}$ 39.831.048/Tahun dan Rp 38.359.260/Tahun. Pendapatan total rumah tangga petani karet Desa Sungai Jalau 3,84 \% lebih besar dari petani karet Desa Teratak, walaupun pendapatan pertanian Desa Taratak lebih besar dari Desa Sungai Jalau, tapi sumber pendapatan non pertanian petani Sungai Jalau 78,45\% lebih besar dari Desa Teratak

Pendapatan per kapita merupakan salah satu indikator makro ekonomi, yang telah lama digunakan untuk mengukur pertumbuhan ekonomi. Berdasarkan perspektif makro ekonomi, indikator ini merupakan bagian yang dapat mengukur tingkat kesejahteraan masyarakat,sehingga dapat menggambarkan kesejahteraan dan kemakmuran masyarakat di suatu wilayah. Semakin tinggi pendapatan per kapita penduduk suatu wilayah maka wilayah tersebut semakin makmur, namun demikian tingginya pendapatan per kapita tidak menjamin bahwa seluruh penduduk telah menikmati kemakmuran. Angka-angka pendapatan per kapita tidak menunjukkan bagaimana seluruh pendapatan tersebut dibagikan, meningkatnya pendapatan per kapita belum diketahui apakah keadaan sebagian besar penduduk yang berpenghasilan rendah telah membaik atau belum. Pendapatan per kapita hanya merupakan gambaran secara umum dari kesejahteraan penduduk (Supadi dan Achmad $\mathrm{R}, 2004)$.

Hasil penelitian menunjukkan bahwa pendapatan total rumah tangga petani karet di Desa Sungai Jalau pertahun, dibagi dengan anggota rumah tnagga maka diperoleh pendapatan perkapita pertahun sebesar
Rp7.966.209,6,sedangkan petani karet Desa Teratak pendapatan perkapita pertahun sebesar Rp 6.393.212, berdasarkan pendapatan perkapita rata-rata sehingga dapat dikatakan, tingkat kesejahteraan petani karet di Desa Sungai Jalau dan Desa Teratak sudah berada pada kondisi sejahtera. Berdasarkan uji significant yang dilakukan, didapat nilai $\mathrm{t}$ hitung lebih besar $t$ tabel 2,021, maka dapat dikatakan terdapat perbedaan tingkat kesejahteraan yang significant pada masyarakat Desa Sungai Jalau dengan Desa Teratak.

Petani Desa Teratak yang menjual produksi karet ke toke luar, harganya lebih tinggi dari petani Desa Sungai Jalau yang menjual ke touke dalam,sehingga pendapatan usahatani karet per hektar petani Desa Taratak lebih besar dari petani Desa Sungai Jalau. Berdasarkan luas lahan rata-rata, petani Desa Sungai Jalau memiliki luas lahan rata-rata lebih besar dai Desa Teratak, ditambah lagi pendapatan non pertanian petani Desa Sungai Jalau juga lebih besar dari Desa Teratak, sehingga pendapatan total rumah tangga yang diterima keluarga petani Desa Sungai Jalauhanya 3,84\% lebih besar dari petani Desa Teratak. Walaupun pendapatan total rumah tangga petani Desa Sungai Jalau hanya 3,84\% lebih besar dari Desa taratak, tapi jumlah anggota rumah tangga petani karet Desa Teratak lebih besar dari petani karet Desa Sungai Jalau, sehingga pendapatan perkapita petani karet Desa Teratak sekitar 20\% lebih rendah dari petani karet Desa Sungai Jalau. Kondisi ini menyebabkan terdapat perbedaan yang significant tingkat kesejahtetaan petani karet Desa Sungai Jalau dengan Desa Teratak.

\section{KESIMPULAN DAN SARAN}

\section{Kesimpulan}

1. Pendapatan bersih usahatani karet per tahun Desa Sungai Jalau sebesar Rp. 15.304.150/Luas garapan (Rp 11.253.051,5/ha) dan pendapatan kerja keluarga sebesar Rp. 24.254.150/Luas garapan, (Rp 17.833.933,8/ha) sedangkan Desa Teratak sebesar Rp. 13.692.636/Luas garapan (Rp 11.316.228,1/ha) dan pendapatan kerja keluarga sebesar Rp.22.206.636/Luas garapan (Rp 18.352.591,7/ha). Pendapatan bersih usaha 
tani karet per hektar petani Desa Teratak lebih besar 0,56\% dari petani Sungai Jalau, sedangkan pendapatan kerja keluarga perhektar petani Desa Terataklebih besar 2,91\% dari Desa Sungai Jalau. Kondisi tersebut disebabkan sedikit lebih tingginya harga jual karet rata-rata petani Desa Teratak dari Petani Desa Sungai Jalau. Luas lahan rata-rata Petani Desa Sungai Jalau lebih besar $12,40 \%$ dari Desa Teratak, sehingga pendapatan bersih yang diterima petani karet Desa Sungai Jalau per luas garapan sekitar 12\% lebih besar dari Desa Taratak dan pendapatan kerja keluarga petani Desa Sungai Jalau 9,22\% lebih besar dari Desa Teratak.

2. Pendapatan perkapita petani di Desa Sungai Jalau rata-rata Rp.7.966.210/tahun, sedangkan Desa Teratak Rp.6.393.210/ tahun, berdasarkan nilai rata-rata pendapatan perkapita, tingkat kesejahteraan petani karet di Desa Sungai Jalau dan Desa Teratak sudah sejahtera. Uji significant yang dilakukan, didapat nilai t hitung lebih besar dari dan $t$ tabel 2,021, maka dapat dikatakanterdapat perbedaan tingkat kesejahteraan yang significant pada masyarakat Desa Sungai Jalau dengan Desa Teratak

\section{Saran}

1. Pentingnya petani memanfaatkan waktu senggangnya untuk meningkatkan pendapatan rumah tangganya, dengan memanfaatkan potensi sumber daya alam yang ada disekitarnya dan petani tidak hanya bergantung pada sektor pertanian saja, tetapi juga harus tanggap terhadap peluang-peluang usaha disektor nonpertanian agar mengurangi resiko ketergantungan sektor pertanian terhadap cuaca dan iklim, serta meningkatkan kesejahteraan.

2. Pendapatan petani didominasi oleh perkebunan karet, diharapkan pemerintah mempriorotaskan program-program terkait perkebunan karet, dalam upaya peningkatan pendapatan rumah tangga petani.

\section{DAFTAR PUSTAKA}

Badan Pusat Statistik. 2011. Riau Dalam Angka. BPS Provinsi Riau. Pekanbaru.

Dajan. 1986. Pengantar Statistika. Penerbit Alfabeta. Bandung

Dinas Perkebunan Kampar. 2013. Luas dan Produksi Karet Kampar. Dinas Perkebunan Kampar

Direktorat Jenderal Perkebunan. 2012. Luas Kebun Karet Indonesia. Dikjenbun

Halim, 2012. Distribusi Pendapatan dan Tingkat Kemiskinan Petani Kopi Arabika di Desa Tanjung Beringin Kecamatan Sumbul Kabupaten Dairi. Skripsi Fakultas Pertanian Universitas Sumatera Utara, Medan.

Hernanto, Fadholi. 1994. Ilmu Usahatani. Penerbit Swadaya. Jakarta

Maryani, 2007. Aneka Tanaman Perkebunan. Pusat pengembangan Penddidikan Universitas Riau. Pekanbaru.

Soekartawi.2002. Prinsip Dasar Ekonomi Pertanian: Teori dan Aplikasinya. PT RakaGrafindoPersada. Jakarta

Supadi dan Achmad Rozany Nurmanaf. 2004. Pendapatan dan Pengeluaran Rumah Tangga Pedesaan dan Kaitannya dengan Tingkat Kemiskinan. http://ejournal.unud.ac.id. Diakses pada tanggal 23Mei 2014.

Suratiyah K, 2006. Ilmu Usahatani. Penebar Swadaya. Jakarta. 